\title{
Neocarzinostatin, Aptamer Conjugates for Targeting EpCAM-positive Tumor Cells
}

\author{
PRASANNA KUMAR ATHYALA ${ }^{1,2}$, JAGAT RAKESH KANWAR ${ }^{2}$, SRUJANA CHITIPOTHU ${ }^{3}$, \\ RUPINDER KAUR KANWAR ${ }^{2}$, SUBRAMANIAN KRISHNAKUMAR ${ }^{1}$, \\ JONATHAN P. WATSON ${ }^{2}$ and JANAKIRAMAN NARAYANAN ${ }^{1}$
}

\author{
${ }^{1}$ Department of Nanobiotechnology, Kamalnayan Bajaj Institute for Research in Vision and Ophthalmology, \\ Vision Research Foundation, Chennai, India; \\ ${ }^{2}$ Nanomedicine-Laboratory of Immunology and Molecular Biomedical Research (NLIMBR), \\ School of Medicine (SoM), Centre for Molecular and Medical Research (C-MMR), \\ Faculty of Health, Deakin University, Burwood, Australia; \\ ${ }^{3}$ Central Research Instrumentation Facility, Kamalnayan Bajaj Institute for Research in Vision and Ophthalmology, \\ Vision Research Foundation, Chennai, India
}

\begin{abstract}
Background/Aim: The aim of this study was to investigate the role of Neocarzinostatin (NCS) conjugated with epithelial cell adhesion molecule (EpCAM) aptamer in EPCAM-positive cancer cells. NCS is an antitumor antibiotic protein chromophore that has the ability to cleave double stranded DNA and can be used as a potential drug for the treatment of EpCAM-positive cancers. EpCAM aptamer is an oligonucleotide ligand that binds specifically to EpCAM, a protein overexpressed in tumor cells. Materials and Methods: NCS was conjugated with EpCAM aptamer using Sulfo-Succinimidyl 6-(3-(2-pyridyldithio) propionamide hexanoate) $L C$-(SPDP) cross-linker to deliver it to EpCAM-positive tumor cells. The conjugates were characterized using polyacrylamide gel electrophoresis $(P A G E)$ and high-performance liquid chromatography (HPLC). Flow cytometry was used to study the binding efficiency of the aptamer and the conjugates in cancer cells. The effect of the conjugate on cancer cells was studied using propidium iodide (PI) to analyze the cell cycle phase changes. The apoptosis assay was performed using the $I C_{50}$ concentration of NCS. Microarrays were performed to study the gene level changes in cancer cells upon treatment with NCS and the conjugate. Results: Flow cytometry revealed significant binding of aptamer and conjugate in the MCF-7
\end{abstract}

Correspondence to: Dr. J. Narayanan, Department of Nanobiotechnology, Vision Research Foundation, Chennai-600006, India. Tel: +91 4428271616 (Ext 1358), e-mail: drjrn15@gmail.com

Key Words: Neocarzinostatin (NCS), Epithelial cell adhesion molecule (EpCAM), microarray, DNA-damage, apoptosis, cell cycle, BrDU, PARP, H2AX, necrosis. and WERI-Rb1 cell lines. Briefly, $62 \%$ in MCF and $30 \%$ in WERI-Rb1 cells with conjugate treated cells $(p<0.005)$. The cell-cycle analysis indicated $G_{2}$ phase arrest in MCF-7 cells and $S$ phase arrest in WERI-Rbl cells $(p<0.005)$. Microarray analysis showed differentially expressed genes involved in cell cycle, DNA damage, and apoptosis. The BrDU assay and the apoptosis assay showed that the expression of $\mathrm{BrDU}$ was reduced in conjugate-treated cells and the PARP levels were increased confirming the double stranded DNA breaks ( $p<0.005)$. In MCF-7 and WERI-RbI cells, most of the cells underwent necrosis $(p<0.005)$. Conclusion: The EPCAM aptamer conjugated NCS showed specificity to EpCAM-positive cells. The effect of the conjugates on cancer cells were impressive as the conjugate arrested the cell cycle and promoted apoptosis and necrosis. The high levels of PARP expression confirmed the DNA breaks upon conjugate treatment. Our study demonstrates that the NCS conjugated with EPCAM can be targeted to cancer cells sparing normal cells.

Cancer treatment without adverse side-effects is a challenge. Chemotherapy is a conventional method for cancer treatment and on a high priority of research due to its off-targeting effects. Chemotherapeutic drugs, however, show limitations of low bioavailability and off-target effects to normal cells and tissues (1). Targeted therapy is a type of cancer treatment where, the drugs can be targeted to the cancer cells using molecules that are uniquely expressed in the tumors (2-4). Targeted therapy can potentially increase bioavailability and lower side-effects. The antibody-drug conjugation approach was initiated in the late 1900 and has shown tremendous potential for targeted cancer therapy (5-7). However, several antibody conjugates have been tested against many cancers, 
and an adverse reaction is commonly encountered. NCS antibody conjugate in Phase II clinical trials resulted in thrombocytopenia and acute allergic reactions in patients for which the exact reason is unknown $(8,9)$. Aptamers are the small oligonucleotide or peptide sequences that bind specifically to a target molecule (10). The epithelial cell adhesion molecule (EpCAM) is a transmembrane glycoprotein involved in proliferation, migration, differentiation and in various signaling pathways in cancers (11). EpCAM plays a substantial role in tumorigenesis and metastasis and is expressed in the majority of epithelial tumors. Hence, targeting EpCAM may provide an approach for treating cancers (12). The specificity of EpCAM aptamers has already been reported in the literature $(13,14)$.

Toxin-based therapy has gained attention for treating cancers in recent years as they are highly potent and can kill tumor cells at very low dosages (15-18). NCS obtained from Streptomyces carzinostaticus (19-21) is a single chain acidic protein (113 amino acids, $11 \mathrm{kDa}$ ) bound to an enediyne chromophore that contains an active naphthoate ester. NCS intercalates with DNA, by positioning the diene into the minor groove. The diradical reacts with $\mathrm{C} 4$ ' and $\mathrm{C} 5$ '-atoms of the deoxyribose sugar, usually at deoxyadenosine and thymidine residues of DNA (22).

NCS antibody conjugates have been used for targeting pancreatic cancer (23) and melanoma (24) however due to the adverse reactions elicited in patients, stage II clinical trials were not continued (25). In order to overcome the immune responses elicited by earlier study, an aptamer was synthesized against EpCAM. Our group had already delivered antitumor drugs to the tumor cells using EpCAM aptamer as a ligand $(13,26)$. We have also investigated the biophysical interaction between NCS and EpCAM aptamer (27). In continuation, in this study, we conjugated EpCAM aptamer with NCS toxin as mentioned in Figure 1. The conjugates were synthesized using Sulfo-LC-SPDP cross-linker and characterized by HPLC and SDS-PAGE. We investigated its effects on MCF7 and WERI-Rb1 cells. The impact of the conjugate on cell viability, cell cycle, apoptosis and the whole transcriptome was evaluated. Whole transcriptome microarray analysis was also performed to identify changes in the expression of genes caused by the NCS conjugate.

\section{Materials and Methods}

Conjugation of neocarzinostatin with EpCAM aptamer. The heterobifunctional crosslinker Sulfo-LC- N-succinimidyl-3-(2pyridylodithio) propionate (Sulfo-LC-SPDP, Thermo Scientific, USA) was used to conjugate NCS with EpCAM aptamer (28). Briefly, EpCAM aptamer 5'S-S-GCGACUGGUUACCCGGUCG-3' (Dharmacon Inc, Lafayette, CO, USA) with and without fluorescein (FAM) was diluted using RNAse and DNAse free water to make $100 \mu \mathrm{M}$ concentration. The aptamer was reduced using $2 \mathrm{mM}$ Dithiothreitol (DTT, Sigma-Aldrich, Bangalore, India). Excess DTT was removed using Sephadex Columns (NAP-5 columns, G25-DNA grade column, GE Healthcare, Bangalore, India). NCS solution was treated with the SPDP cross-linker for $1 \mathrm{~h}$ at RT using constant stirring. The unreacted SPDP was removed using Zeba micro spin desalting columns (Thermo Scientific, Carlsbad, California, USA). The NCS-SPDP solution was added dropwise to a 5-fold molar excess of reduced EpCAM aptamer and reacted overnight at $4^{\circ} \mathrm{C} .2$ $\mathrm{mM}$ iodoacetamide (Sigma, Bangalore, India) was added to the reaction mixture to block the unreacted aptamer. The conjugation reaction was monitored through the appearance of pyridine 2-thione at $340 \mathrm{~nm}$ using a multimode microplate reader (Spectramax, Molecular Devices M4, Sunnyvale, California, USA). The unconjugated aptamer was washed with PBS (10 mM sodium phosphate, $150 \mathrm{mM} \mathrm{NaCl}$ ( $\mathrm{pH} 7.2$ ), and the conjugate was eluted with $10 \mathrm{mM}$ sodium phosphate, $1 \mathrm{M} \mathrm{NaCl}$ as per the previous reports (28). The conjugates were then subjected to the spin filtration (Spin Filter columns, Millipore, Bangalore, India) to remove the unreacted salts and reactants. Filtered conjugates were then stored at $-80^{\circ} \mathrm{C}$ until being used for in vitro studies.

\section{Characterization of Conjugates}

Gel retardation assay. The Ep-NCSFi conjugates were identified using SDS-PAGE (Polyacrylamide gel electrophoresis). NCS alone $5 \mu \mathrm{M}, \mathrm{NCS}-\mathrm{SSEpFi}$ conjugate $5 \mu \mathrm{M}$ and the DTT-reduced NCSSSEpFi $5 \mu \mathrm{M}$ were diluted with $1 \mathrm{X}$ protein loading buffer $(50 \mathrm{mM}$ Tris $\mathrm{pH} 7.5 ; 2 \%$ SDS; $8 \%$ glycerol; $0.5 \%$ bromophenol blue), and the samples were run on a $18 \%$ gel. The samples loaded were Native NCS, Native aptamer, the prepared conjugate and DTTreduced conjugate.

High-performance liquid chromatography (HPLC) analysis. The Ep-NCSF: aptamer conjugates were characterized through a reversed phase-HPLC to analyze the conjugates as described earlier (29). The purification of the Ep-NCSFi conjugate was carried out using Agilent Zorbax oligo column (1200 series). The mobile phase contained $20 \%$ acetonitrile (A) and $80 \% 0.02 \mathrm{M}$ sodium phosphate (monobasic, B) pH 7.0, (B-A) $+2.0 \mathrm{M} \mathrm{NaCl}$. A linear gradient of $0 \% \mathrm{~B}$ to $100 \% \mathrm{~B}$ in $120 \mathrm{~min}$ with a flow rate of $0.5 \mathrm{ml} / \mathrm{min}$ was used for separation. The gradient was controlled by the Agilent software. The column temperature was maintained at $25^{\circ} \mathrm{C}$. The fractions were collected at one-minute intervals and absorbance measured at $260 \mathrm{~nm}$ and $480 \mathrm{~nm}$ using Diode Detection Array (DAD). The fractions were concentrated using Spin filter columns (Amicon-3KDa), and the purified conjugates were also checked for the excitation and emission at $480 \mathrm{~nm}$ and $520 \mathrm{~nm}$ using a multimode plate reader.

\section{In Vitro Evaluation of Ep-NCSFi conjugates} Cell culture. WERI-Rb1 retinoblastoma cells (RIKEN BioResource Center, Ibaraki, Japan) were maintained in RPMI 1640 (GIBCO, Rockville, MD) supplemented with $10 \%$ foetal bovine serum (FBSGIBCO, Rockville, MD) and $0.1 \mathrm{X}$ penicillin-streptomycin antibiotics (Himedia, Bangalore, India). MCF-7 breast cancer (ATCC, Manassas, VA 20108, USA) and MIOM1 Muller glial cell line [a gift from Dr. G. A. Limb (UCL Institute of Ophthalmology, London, England)], were maintained in DMEM 1640 (GIBCO, Rockville, MD) supplemented with $10 \%$ Foetal bovine serum and $0.1 \mathrm{X}$ penicillin-streptomycin antibiotics (Himedia, Bangalore, India). All cell lines were maintained in $5 \% \mathrm{CO}_{2}$ saturated humidified incubator at $37^{\circ} \mathrm{C}$. 

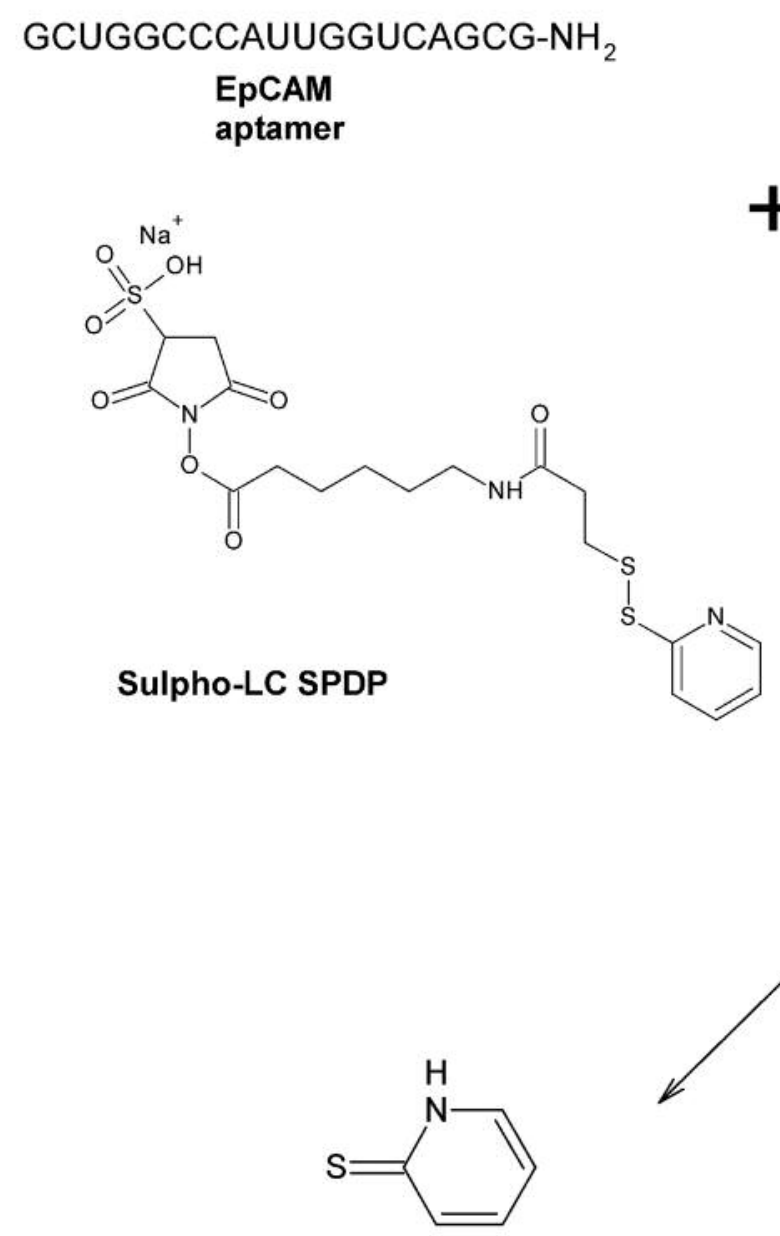

Pyridone 2 Thione

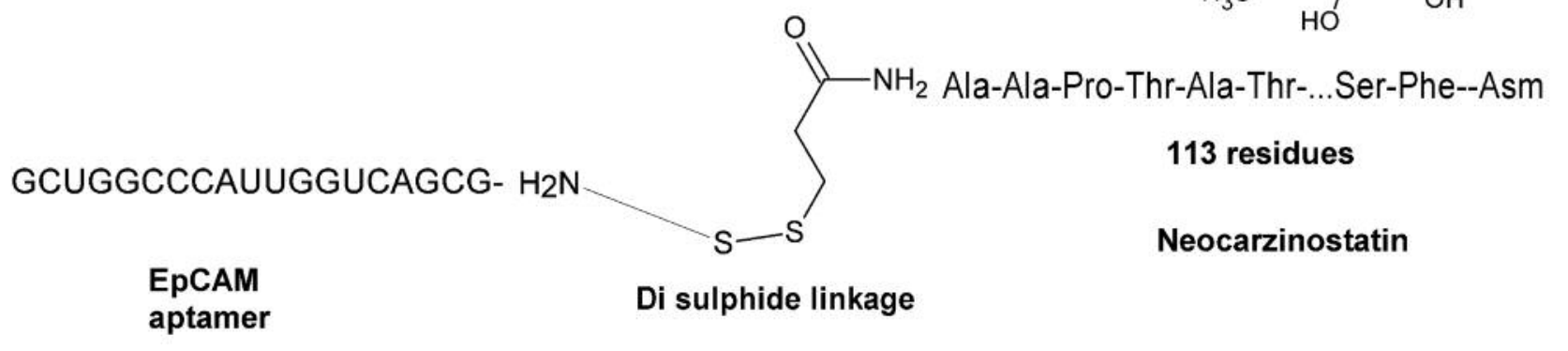

$\mathrm{H}_{2} \mathrm{~N}$-Ala-Ala-Pro-Thr-Ala-Thr-...Ser-Phe--Asm

113 residues

Neocarzinostatin<smiles>CN[C@H]1C(OC2C3C=CC(C4COC(=O)O4)=C3C[C@H]2OC(=O)c2c(O)ccc3c(C)cc(OC)cc23)OC(C)C(O)C1O</smiles>

\section{EpCAM Aptamer Neocarzinostatin Conjugate}

Figure 1. Schematics of Neocarzinostatin-EpCAM aptamer conjugate synthesis using Sulfo-LC-SPDP chemistry. 
Flow cytometry analysis. The binding efficiency of aptamer and Ep-NCSFi conjugate with EpCAM cells was measured using a Flow cytometer (BD FACSCalibur, BD Lifesciences, Franklin Lakes, NJ, USA). Briefly, $2 \times 10^{6}$ cells WERI-RB 1, MCF-7 and MIOM1 cell lines were washed twice with $1 \mathrm{X}$ PBS and incubated with $0.1 \mu \mathrm{M}-1 \mu \mathrm{M}$ of native aptamer and Ep-NCSFi conjugates in $100 \mu \mathrm{l}$ DMEM media for $1 \mathrm{~h}$. A control sample for all the three cell lines was maintained to gate the cells for Flow cytometry analysis. The cells were centrifuged at $1500 \mathrm{RPM}$ post-incubation for $5 \mathrm{~min}$, the pellet was washed twice with 1X PBS and suspended in sheath fluid. Cells were acquired using a green laser $(480 \mathrm{~nm})$ and analyzed for FITC expression based on the histogram obtained.

Fluorescence microscopy. Fluorescence microscopy was used to study the aptamer and Ep-NCSFi conjugates binding in cancer and normal cells. Approximately $1 \times 10^{3} /$ well WERI-Rb1, MCF-7, and MIOM1 cells, were seeded on Poly-L-Lysine coated coverslips placed in 24-well plates. Post-seeding, cells were incubated with $150 \mathrm{nM}$ concentrations of SSEpFi alone, Ep-NCSFi conjugate and $\mathrm{NCS}$ alone at $37^{\circ} \mathrm{C}$ for $1 \mathrm{~h}$. Post incubation, cells were washed twice with 1X PBS, fixed with cold $4 \%$ paraformaldehyde (PFA). Cells were then washed twice with $1 \mathrm{X}$ PBS and counterstained with DAPI for 10 min and images were acquired with Zeiss fluorescence microscopy and analyzed using Axio Vision software.

Gene Expression Study by Microarray Analysis Cell Culture and RNA isolation. Briefly, $2 \times 10^{6} \mathrm{MCF}-7$ cells/well were seeded in 6 -well plates and allowed to grow overnight. The cells were treated with NCS alone $(100 \mathrm{nM})$ or NCS-EpFI conjugated $(50 \mathrm{nM})$ and incubated for $24 \mathrm{~h}$. Cells were trypsinized after incubation and washed twice with $1 \times \mathrm{PBS}$. Total RNA was isolated from the untreated control cells $(\mathrm{C} 1, \mathrm{C} 2)$, NCS $(\mathrm{N} 1, \mathrm{~N} 2)$ and NCS Conjugate (NC1, NC2) treated cells in duplicates using Qiagen RNeasy mini kit (Qiagen, Valencia, CA, USA). RNA was checked for quality and quantity using BioSpec-nano (Shimadzu, Kyoto, Japan). Total RNA was diluted as per the requirement for further microarray analysis.

Experimentation protocol. The Affymetrix microarray platform was used for gene expression study. Briefly double-stranded cDNA was synthesized from $100 \mathrm{ng}$ total RNA using poly-A RNA controls by reverse transcriptase PCR. The further in vitro transcription was done to synthesize biotin labeled amplified RNA (aRNA) using 3' IVT PLUS Reagent Kit (902416, GeneChip 3' IVT PLUS Reagent Kit, Thermofisher scientific, Bangalore, India). RNA was purified and quantified using BioSpec-nano. Further, it was fragmented and observed in $1 \%$ Agarose gel for the fragmentation pattern. Fifteen $\mu \mathrm{g}$ of labeled fragmented aRNA was used for preparing the hybridization cocktail. One hundred and thirty $\mu \mathrm{l}$ of hybridization cocktail was loaded on to the GeneChip PrimeView Human Gene Expression Array cartridges and hybridized for $16 \mathrm{~h}$ in rotation at 60 $\mathrm{rpm}$ and $45^{\circ} \mathrm{C}$ using Gene Chip Hybridization oven 640. After hybridization, the array cartridges were washed and stained using the Affymetrix Fluidic station 450. Stained arrays were scanned using Affymetrix GeneChip scanner (3000 7G) at $570 \mathrm{~nm}$.

Microarray data analysis. The Raw Expression Array feature intensity data (.CEL file) generated from the scanner was processed initially with the Affymetrix Expression Console software (version 4.0) using RMA algorithm to generate probeset summarization values '.CHP' files. Normalized Raw data were submitted to NCBI Gene Expression Omnibus (Accession number GSE69160). Further microarray statistical analysis, fold change analysis, and biological interpretation were done using the Gene Spring (Version 13.0) software. The analysis was done for three different samples in biological duplicates, i.e., control; NCS treated cells, and EP-NCSFi conjugate treated cells $(\mathrm{C} 1$, $\mathrm{C} 2, \mathrm{~N} 1, \mathrm{~N} 2, \mathrm{NC} 1$, and $\mathrm{NC} 2$ ). The .CEL files were imported to Gene spring software (Version 13.0-GX). Quality control was performed based on filtration of probe set by expression and by error. The interpretation was done individually between control $v s$. NCS treated, control vs. EP-NCSFi conjugate treated and NCS vs. EP-NCSFi Conjugate averaged samples of duplicate treatments. The statistical analysis was also performed separately between the three groups. Statistics was applied using moderate T-Test with the asymptotic computation of $p$-value and multiple testing correlations using Benjamini-Hochberg FDR. The downstream entities with a fold change of $>2.0$ with a $p$-value of $<0.05$ were taken further for fold change interpretation. The fold change threshold was kept two-fold. The gene list of fold change for both the control vs. NCS and Control $v s$. EP-NCSFi conjugate treated cells were analyzed for common gene set of differentially expressed genes using Venn diagram. Further biological interpretation on the differentially expressed gene list of NCS vs. EP-NCSFi Conjugate analysis was performed for understanding the differential expression upon EP-NCSFi conjugate treatment. The differentially expressed gene set data was taken further for Gene Ontology (GO) analysis with a $p$-value of 0.05 .

BRDU, H2AX and PARP assay. Bromodeoxyuridine (BrDU) incorporation assay was performed using the BrDU assay kit (BD pharming 562253, Excel Bioscience, Chennai, India). Briefly, $2 \times 10^{6}$ cells (MCF-7 and WERI-Rb1) were grown in a 6-well plate, and the cells were treated with the NCS and Ep-NCSFi conjugates and incubated for 12 and $24 \mathrm{~h}$. The cells were then washed twice with $1 \mathrm{XPBS}$ and processed with $10 \mu \mathrm{M}$ final concentration of BrdU in cell culture media. The cells were then incubated for $12 \mathrm{~h}$, washed twice with $1 \mathrm{X}$ PBS and treated as per the standard protocol given in the manufacturer's kit. Accordingly, the cells were washed and fixed with BD Perm wash buffer and incubated with anti-BrDU, anti$\mathrm{H} 2 \mathrm{AX}$ and cleaved anti-PARP antibodies. The cells were incubated for $45 \mathrm{~min}$ at RT and washed twice with $1 \mathrm{X}$ BD wash buffer and acquired through the flow cytometer. Cells were grown on the coverslips, and the same procedure was followed for the microscopic analysis. The cells were fixed and stained with the DAPI. The images were acquired with a Zeiss fluorescence microscopy. Bangalore, India and analyzed using Axio Vision software.

Cell cycle assays by flow cytometry. MCF-7 and WERI-Rb1 cells were cultured in 6-well plates, incubated with Native NCS $(200 \mathrm{nM})$, and Ep-NCSFi conjugates (100 nM) for $24 \mathrm{~h}$. Post-incubation, cells were collected, washed twice with $1 \mathrm{X}$ cold PBS and fixed with $70 \%$ cold ethanol. Cells were washed twice with 1XPBS and incubated with RNase $(10 \mu \mathrm{g} / \mathrm{ml})$ and Propidium Iodide (PI-50 $\mu \mathrm{g} / \mathrm{ml})$ at $37^{\circ} \mathrm{C}$ for $3 \mathrm{~h}$. Post incubation, cells were washed twice with 1XPBS, suspended in sheath fluid and acquired through the Flow cytometer.

Apoptosis assay. MCF-7 and WERI-Rb1 cells were grown at a confluence of $60-75 \%$ for $24 \mathrm{~h}$ and incubated with NCS alone $(200 \mathrm{nM})$ or Ep-NCSFi conjugates $(100 \mathrm{nM})$ for $24 \mathrm{~h}$. Postincubation, cells were washed twice with $1 \mathrm{X}$ PBS and fixed with $4 \%$ PFA. Cells were washed twice with $1 \mathrm{X}$ PBS and incubated 


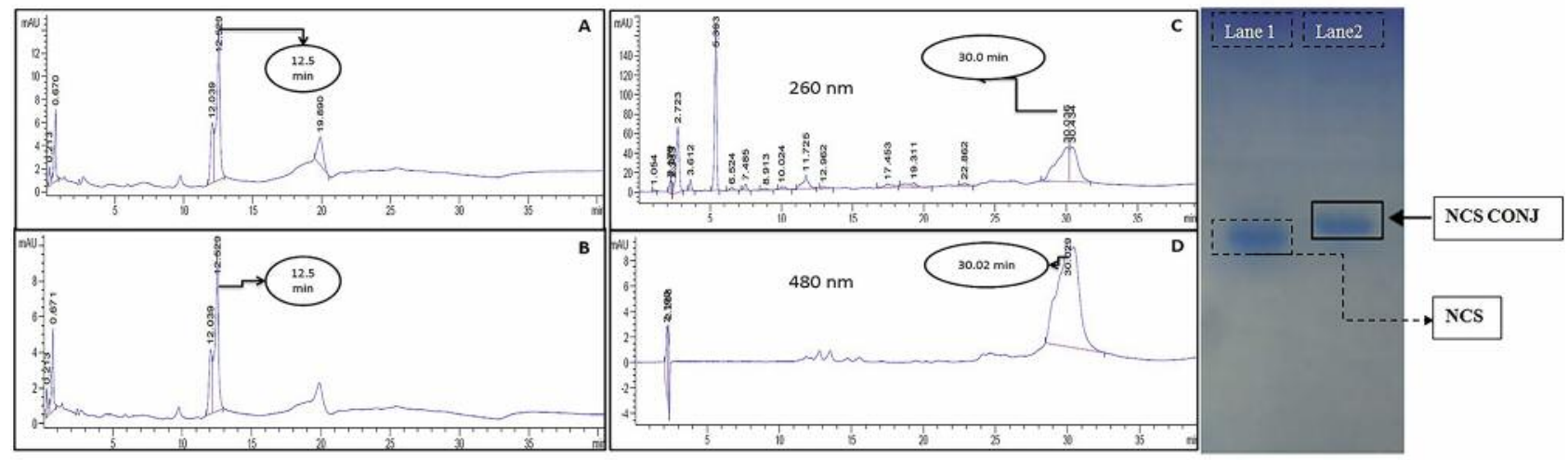

Figure 2. Characterization of EpCAM RNA aptamer conjugate: (A\&B) the HPLC chromatographs of NCS and Ep-NCSFi aptamer conjugate showed the confirmation of conjugation by the difference in the retention time between the NCS (12.5 min at $260 \mathrm{~nm}$ and $480 \mathrm{~nm})$ and the (C\&D)Ep-NCSFi conjugate $(30.0,30.02$ at $260 \mathrm{~nm}$ and $480 \mathrm{~nm})$. (E) The SDS-PAGE analysis showed the proof-of-concept of the conjugation initially with the difference in the bands between the NCS and the Ep-NCSFi conjugate with 18\% gel stained with Coomassie blue.

with Annexin-V FITC and PI according to the manufacturer's protocol (556547, BD Pharmingen ${ }^{\mathrm{TM}}$, San Jose, CA, USA) for $1 \mathrm{hr}$ at $4^{\circ} \mathrm{C}$. Further, cells were washed twice with PBS and acquired through the Flow cytometer.

Trypan blue exclusion analysis of cell viability. MCF-7 and WERI$\mathrm{Rb} 1$ cells were seeded in 96-well plate at a cell density of 6000/well. Different concentrations ( $100 \mathrm{nM}, 200 \mathrm{nM}, 300 \mathrm{nM}, 400 \mathrm{nM} 500 \mathrm{nM})$ of both (NCS and NCS-SSEPFi) were prepared and added to the cells in triplicates. The samples were incubated at $37^{\circ} \mathrm{C}$ in a humidified incubator for 24 h. $100 \mu \mathrm{l}$ of trypan blue dye was added to the cells, and the number of dead cells which had taken up the dye was counted in the hemocytometer under a compound microscope. The procedure was repeated for all the wells, and triplicate value and the percentage cytotoxicity was calculated by using the standard formula.

Statistical analysis. The statistical analysis for the microarray was done using Gene Spring software and the correlation between the $\mathrm{NCS}$, and the conjugate were performed using Benjamini-Hochberg algorithm, where duplicates of Control, NCS, and the conjugates were considered, and the statistics were performed between the Control vs. NCS and Control vs. Conjugate. The $p$-value was set to be $p<0.05$ which was deemed to be significant. The statistics for the binding assay, cell cycle assay, apoptosis assay and the trypan blue assay was performed with Student $t$-test, and the values were $p<0.05$ and $p<0.001$ which were considered to be significant.

\section{Results}

Conjugation and characterization. Conjugation of NCS with EpCAM aptamer (SSEpFi) was performed using Sulfo-LCSPDP cross-linker, and the reaction was monitored by measuring the absorbance at $340 \mathrm{~nm}$ using a multi-mode microplate reader. The appearance of the absorption peak at $340 \mathrm{~nm}$ confirmed the release of Pyridine-2-thione that was produced as a by-product (28) during the conjugation reaction. The HPLC results indicated that NCS was eluted from the Zorbax oligo column at 12.5 th min, whereas the conjugate eluted at 30.0 th $\mathrm{min}$. Measurement of absorbance at $260 \mathrm{~nm}$ and $480 \mathrm{~nm}$ confirmed the presence of the protein and the aptamer respectively in the conjugate (Figure 2A, B, $\mathrm{C}$ and $\mathrm{D})$. The conjugation was further confirmed by SDSPAGE (Figure 2E).

\section{In vitro evaluation of NCS-aptamer conjugates}

Flow cytometry and fluorescence microscopy. The native aptamer and the conjugate showed better binding profiles in MCF-7 breast cancer cells and WERI-Rb1 retinoblastoma cells compared to MIOM1 Muller glial cells. Binding of the native aptamer and Ep-NCSFi conjugate were found to be $62 \%$ and $35 \%$ respectively for MCF-7 cells with the $\mathrm{IC}_{50}$ values (Figure 3A). Native aptamer and conjugate were found to have a binding of $35 \%$ and $30 \%$ respectively for WERI-Rb1 cells at the $\mathrm{IC}_{50}$ (Figure 3B). MIOM1 cells (deprived of EpCAM expression) showed a very weak binding ( 3 and 10\%) for aptamer and conjugates respectively at the $\mathrm{IC}_{50}$ value (Figure 3C).

The results were confirmed by immunofluorescence that revealed that the native aptamer and conjugates were bound to the cell membrane. Both FITC labeled native aptamer and aptamer conjugates showed higher levels of membrane positivity in MCF-7 cells (Figure 3D) than WERI-Rb1 cells (Figure 3E) and conjugate did not bind to MIOM1 cells. The above results indicated the specificity of the aptamer and conjugate to EpCAM positive cells (Figure 3F).

\section{Gene expression by microarray analysis}

Expression profiling of genes. Microarray analysis was performed using the Gene Spring Software. 1,714 genes were found to be differentially expressed in NCS treated, and 747 


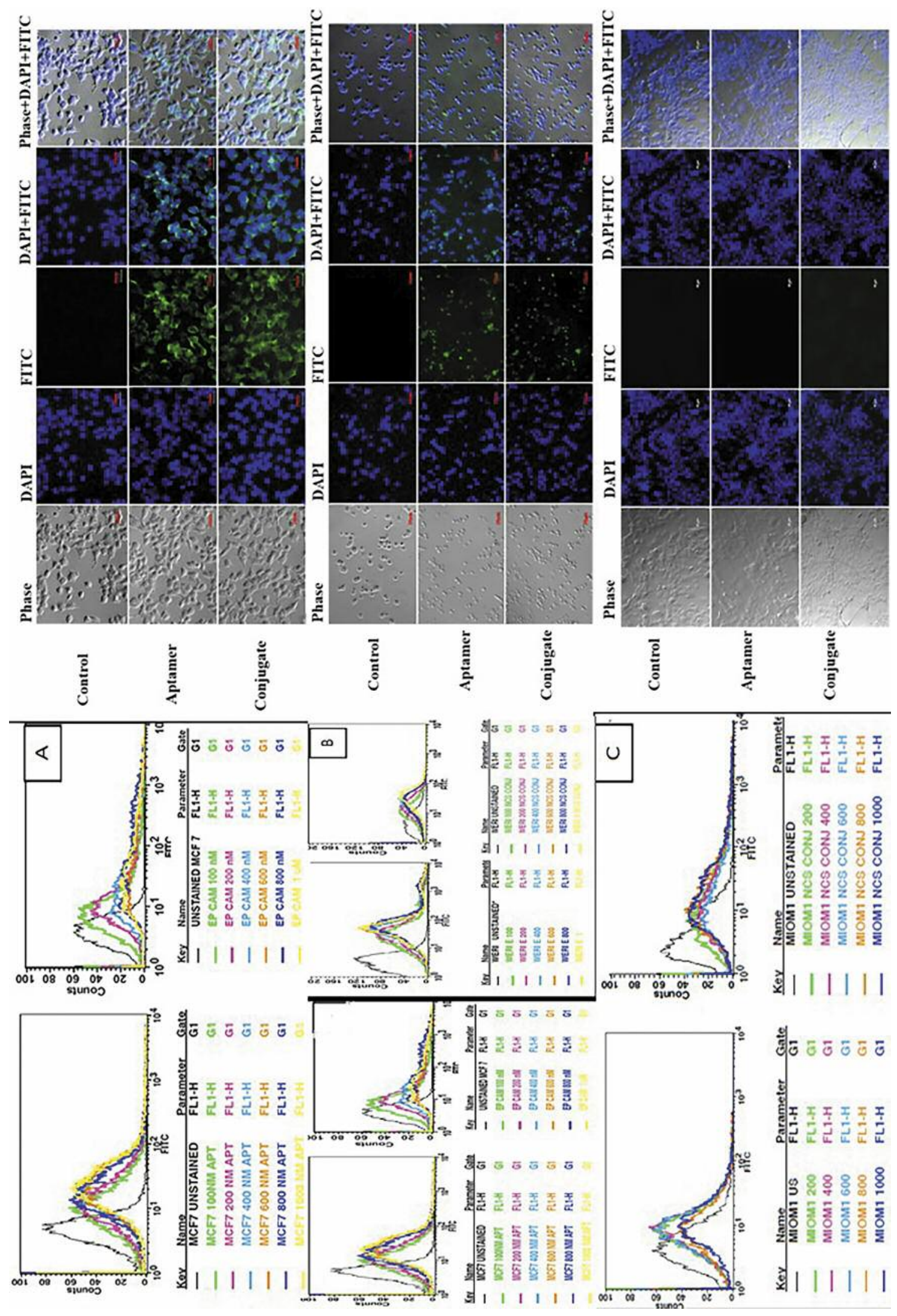


genes in NCS conjugate treated cells with a normalized $p$ value $<0.05$ and a fold change threshold of 2 against the control sample. The gene entities between the control vs. NCS treated, and control vs. Ep-NCSFi conjugate treated cells were overlapped; the overlapped genes revealed a participation of a considerable number of transcription factors, to show the targeted therapy of the NCS (MCF-7) (Figure 4A).

The Gene Ontology (GO) analysis showed the biological processes that are altered in both NCS and Ep-NCSFi conjugate treated cells. The differential process observed in NCS- treated cells include cellular events such as cell-cycle phase, mitotic process, regulation of cell cycle, cell-cycle checkpoint, cell division, apoptotic process, DNA excision, programmed cell death, DNA-template transcription, termination and histone exchange. The Ep-NCSFi conjugate treatment displayed significant changes in biological process (Figure 4B) such as DNA replication-independent nucleosome assembly, histone exchange, DNA conformation change, cell cycle, protein complex biogenesis, cell morphogenesis involved in differentiation, adherens junction organization, mitotic cell cycle, etc..

GO analysis showed differential molecular functions in NCS-treated cells such as protein binding, heterocyclic compound binding, purine NTP-dependent helicase activity, ATP binding, DNA-dependent ATPase activity, helicase activity RNA polymerase II carboxyl-terminal domain kinase activity, ARF GTPase activator activity, etc. (Figure 4B). EpNCSFi conjugate treatment displayed differential molecular functions that included, protein binding, anion binding, alpha-catenin binding, carbohydrate derivative binding, calmodulin-dependent protein phosphatase activity, and RSMAD binding. Cell component genes induced by NCS conjugate included encode (Encyclopedia of DNA Elements) for condensed chromosome kinetochore, mitochondrial matrix, protein - DNA complex, DNA bending complex and DNA packing complex (Figure 4B).

GO analysis with NCS and Ep-NCSFi conjugate treatment displayed the cell component genes (Figure 4B) encoding for pyruvate dehydrogenase complex, condensed nuclear chromosome, centromere region, condensed chromosome, eukaryotic translation initiation factor 4F complex, carboxylterminal domain protein kinase complex, and ubiquitin ligase complexes. The clustering analysis of NCS and Ep-NCSFi conjugate-treated cells indicates down-regulated genes involved in apoptotic and cell cycle processes.

Kyoto Encyclopaedia of Genes and Genomes (KEGG) pathway analysis and Natural Language Processing (NLP) networks. KEGG analysis was performed using online DAVID software to find the gene interaction involved in cancer pathways (30). KEGG analysis revealed highly deregulated genes participating in the cell cycle process which included E2F2, E2F5, CDC20, MYC, and genes involved in small lung cancer, and TGF-beta signaling pathways. The KEGG analysis helped to reveal the deregulated genes involved in post treatments of NCS and Ep-NCSFi conjugate in the breast cancer tumor models. Also, KEGG pathway analysis revealed increased expression of histone molecules like $\mathrm{H} 2 \mathrm{AX}$, which clearly indicated the activation of DNA damage repair mechanism. Cell-cycle checkpoint genes were up-regulated including BCL2 and cyclins (Table I). In the microarray results, NLP networks showed the direct biological link between the genes and processes that were highly up-regulated or highly downregulated. The results clearly indicated that the differentially expressed genes upon treatment with Ep-NCSFi conjugate were involved in apoptosis and necrosis (Figure 5A and B).

Gene expression studies were performed to investigate the possible effect of NCS conjugate involved in targeting the drug directly to the cancer cells. The list of genes associated with the EpCAM has led us to investigate further the effect of the conjugate on different cancer cells having EpCAM expression.

BrDU, H2AX and PARP assay. BrDU incorporation assay revealed that the BrDU uptake is higher in untreated cells (WERI- Rb1 \& MCF-7) than NCS and conjugate-treated cells indicating a reduction in cell proliferation. Consequently, the expression of histone molecule (H2AX), a significant regulator of the DNA repair mechanism was observed to be at elevated levels in the conjugate-treated cells (Figure 6B,C and D). Cleaved PARP level was found to be increased in the conjugate-treated cells as this enzyme recruits the $\alpha-\mathrm{H} 2 \mathrm{AX}$ through serine 139 during DNA repair response indicating the induction of an early DNA damage response.

Figure 3. The EPCAM aptamer binding profiles: $(A \& D)$ The MCF-7 cells showed a significant EpCAM aptamer and Ep-NCSFi conjugate binding to the cells with increase in the concentration of both aptamer and the Ep-NCSFi conjugate through flow cytometry. The fluorescence microscopy revealed the membrane positivity for aptamer and the Ep-NCSFi conjugate treatment. (B\&E) The WERI Rb1 cells showed the promising binding of both aptamer and the Ep-NCSFi conjugate, the fluorescence microscopy also revealed the membrane positivity of the aptamer and the Ep-NCSFi conjugate. (C\& $F)$ The MIOM1 (Normal Muller Glial cells) showed poor aptamer and Ep-NCSFi conjugate binding to the cells, the fluorescence microscopy also revealed no binding of the aptamer or Ep-NCSFi conjugate even with the higher concentrations. Results $=$ Mean $\pm S E M) * p<0.05, * * p<0.01$ and $* * * p<0.001$. 
A
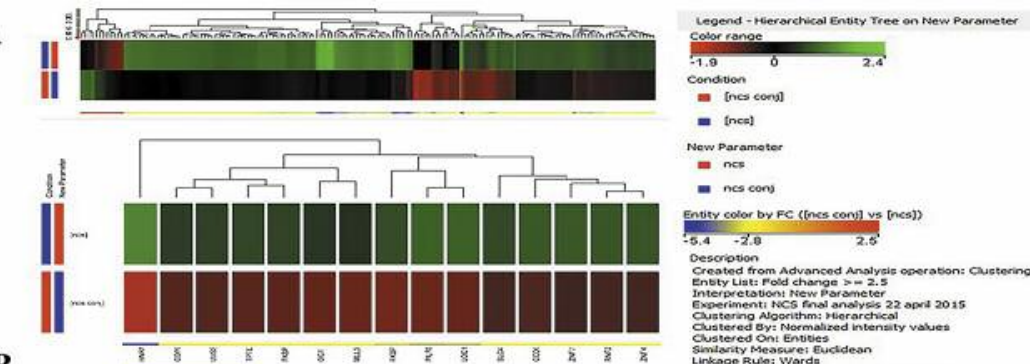

- Inces)

Now

nes con

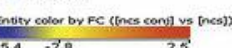

$-5.4-2.0$
Descriotion

B
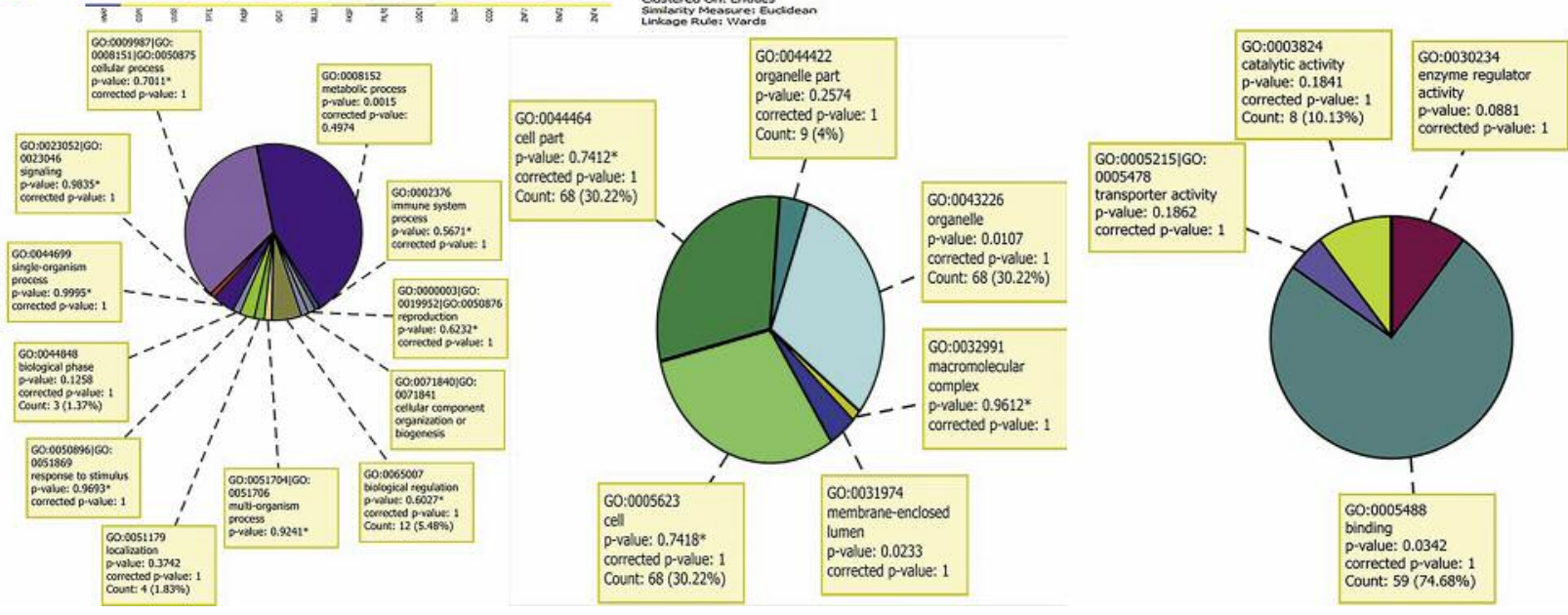

Figure 4. Microarray Gene Expression Studies: (A) Cluster analysis of the Ep-NCSFi conjugate treated cells revealed the genes responsible for the Apoptosis and Necrosis, through an evidence of DNA damage. (B) The Gene Ontology (GO) analysis showed the biological processes, cell component processes and molecular functions of the differentially expressed genes between the NCS and Ep-NCSFi conjugate treatments with significant p-values.

Trypan blue cell viability assay. Trypan blue cell viability assay revealed the $\mathrm{IC}_{50}$ value of $50 \mathrm{nM}$ for Ep-NCSFi conjugate and $150 \mathrm{nM}$ for NCS in MCF-7 cells (Figure 7A). The $\mathrm{IC}_{50}$ value was found to be $75 \mathrm{nM}$ and $300 \mathrm{nM}$ for EpNCSFi-conjugate and NCS respectively in WERI-Rb1 cells (Figure 7B).

Cell cycle and apoptosis assay. Cell-cycle assay revealed that $78 \%$ of MCF-7 cells were arrested in 'G2' phase by NCS treatment and $86 \%$ by Ep-NCSFi- conjugate treatment (Figure 5). Interestingly, WERI-Rb1cells showed " $S$ " phase elongation leading to arrest of $29 \%$ from treatment with NCS and $45 \%$ from treatment with EpNCSFi- conjugate (Figure 6A).

The effect of toxin and the conjugate on cancer cells was revealed by an apoptosis/necrosis assay using PI and annexin. The toxin had a direct impact on DNA damage and consequently the cells undewent necrosis. The native toxin resulted in $47 \%$ necrosis and the conjugates resulted in $50 \%$ necrosis in WERI-Rb1 cells (Figure 7E). Similarly, native toxin caused $24 \%$ necrosis and the conjugate caused $32 \%$ necrosis in MCF-7 cells (Figure 7D). The NCS and EpNCSFi conjugate showed $5.59 \%$ and $8.09 \%$ of late apoptosis in WERI-Rb1 cells, respectively. In the case of the MCF-7 cell line, NCS, and the Ep-NCSFi conjugate brought about 2.4 and $2.1 \%$ of late apoptosis, respectively.

\section{Discussion}

The selectivity and specificity of aptamers to tumor cells have been reported earlier (31). Gelonin toxin has been delivered to prostate cancer cells using anti-PSMA aptamer (32). In this study, the potent DNA damaging anti-tumor antibiotic protein NCS was conjugated with the EpCAM aptamer for delivering NCS precisely to cancer cells.

Since aptamers by themselves are non-immunogenic and can carry the toxic payloads to cancer cells with minimal side effects (33), we conjugated NCS to the EpCAM aptamer in order to target EpCAM positive cells. The ability of the conjugate to induce DNA breaks in the cancer cells leading to ' $\mathrm{G}_{2}$ ' phase arrest and apoptosis or necrosis is in agreement with an earlier report $(34,35)$. Microarray analysis revealed the dominant genes that are highly expressed in MCF-7 cells treated with NCS and conjugate. Evidence revealing the involvment of DNA damage response signaling pathways in conjugate-treated cells is in agreement with earlier reports on 

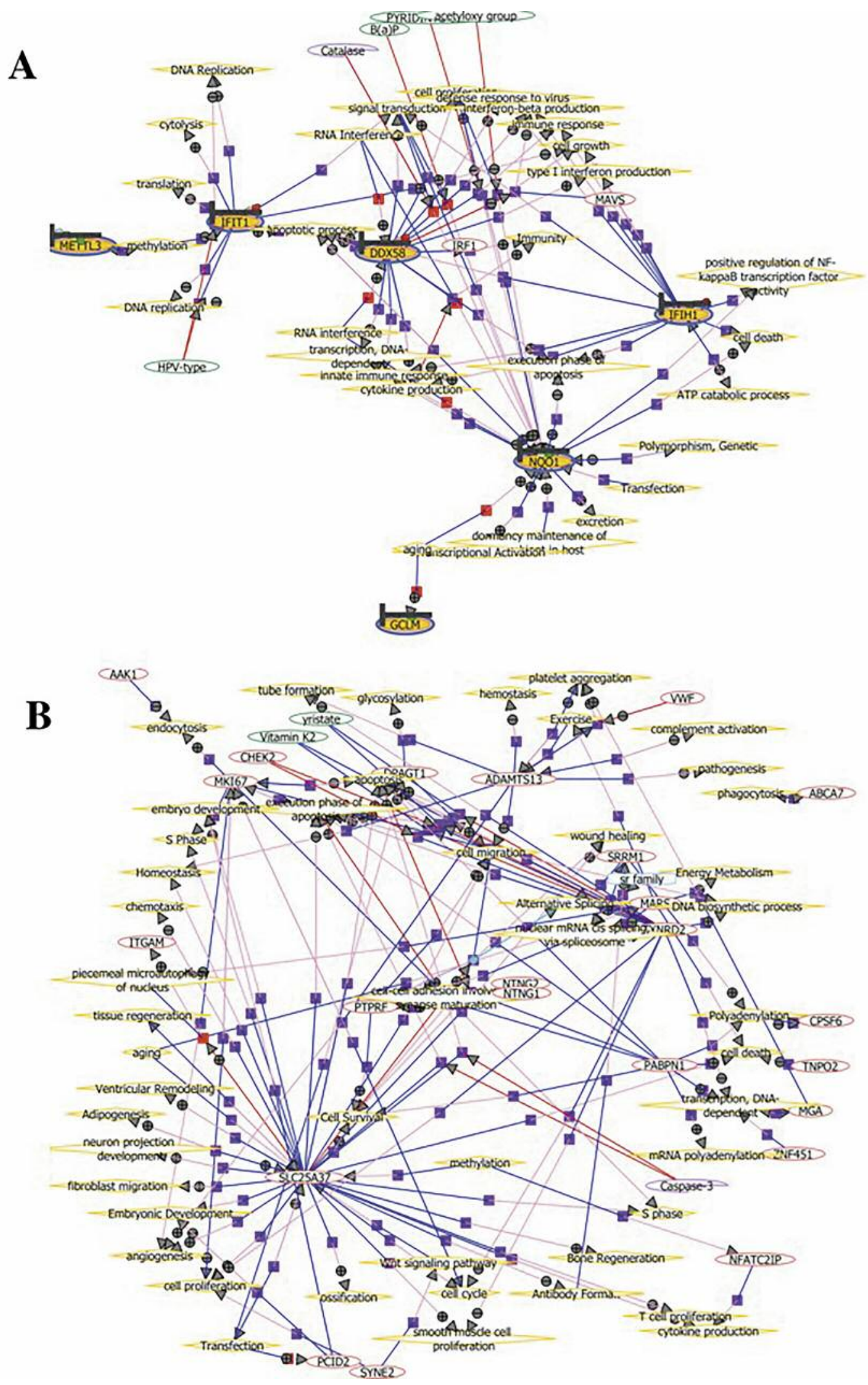

Figure 5. Gene spring analysis of NLP showed the Network of genes and process involved with NCS and NCS-EpCAM conjugate treatments. 
Table I. Selected genes (both up-regulated and down-regulated) with KEGG pathways using DAVID software.

\begin{tabular}{|c|c|c|}
\hline ID & Gene Name & KEGG_PATHWAY \\
\hline$A B C A 3$ & ATP-binding cassette, sub-family A ( $\mathrm{ABC} 1)$, member 3 & $\mathrm{ABC}$ transporters \\
\hline CNOT4 & CCR4-NOT transcription complex, subunit 4 & RNA degradation \\
\hline DDX58 & DEAD (Asp-Glu-Ala-Asp) box polypeptide 58 & $\begin{array}{l}\text { RIG-I-like receptor signaling pathway, hsa04623: } \\
\text { Cytosolic DNA-sensing pathway }\end{array}$ \\
\hline$O G T$ & $\begin{array}{l}\text { O-linked N-acetylglucosamine (GlcNAc) transferase (UDP- } \\
\text { N-acetylglucosamine:polypeptide- } \\
\text { N-acetylglucosaminyl transferase) }\end{array}$ & O-Glycan biosynthesis \\
\hline ACTN1 & Actinin, alpha 1 & Focal adhesion, Leukocyte transendothelial migration \\
\hline$A P P$ & Amyloid beta (A4) precursor protein & Alzheimer's disease \\
\hline CSNK1A1 & Casein kinase 1 , alpha 1 & Wnt signaling pathway, Hedgehog signaling pathway \\
\hline$C P T 1 B$ & $\begin{array}{l}\text { Choline kinase beta; carnitine palmitoyltransferase } \\
\text { 1B (muscle) }\end{array}$ & $\begin{array}{l}\text { Fatty acid metabolism, PPAR signaling pathway, } \\
\text { Adipocytokine signaling pathway }\end{array}$ \\
\hline$C C N L 2$ & Cyclin L2; chemokine (C-C motif) receptor 6 & $\begin{array}{l}\text { Cytokine-cytokine receptor interaction, } \\
\text { Chemokine signaling pathway }\end{array}$ \\
\hline DNM1 & Dynamin 1 & Endocytosis, Fc gamma R-mediated phagocytosis \\
\hline$G A N A B$ & Glucosidase, alpha; neutral $\mathrm{AB}$ & N-Glycan biosynthesis \\
\hline$G C L M$ & Glutamate-cysteine ligase, modifier subunit & Glutathione metabolism \\
\hline GPAA1 & $\begin{array}{l}\text { Glycosylphosphatidylinositol anchor attachment } \\
\text { protein } 1 \text { homolog (yeast) }\end{array}$ & Glycosylphosphatidylinositol(GPI)-anchor biosynthesis \\
\hline IFIHI & Interferon induced with helicase $\mathrm{C}$ domain 1 & RIG-I-like receptor signaling pathway \\
\hline$L I G 1$ & Ligase I, DNA, ATP-dependent & $\begin{array}{l}\text { DNA replication, Base excision repair, Nucleotide } \\
\text { excision repair, Mismatch repair }\end{array}$ \\
\hline$M A N 2 C 1$ & Mannosidase, alpha, class 2C, member 1 & Other glycan degradation \\
\hline NFAT5 & Nuclear factor of activated T-cells 5 , tonicity-responsive & $\begin{array}{l}\text { Wnt signaling pathway, VEGF signaling pathway, } \\
\text { Natural killer cell mediated cytotoxicity, T cell receptor } \\
\text { signaling pathway, B cell receptor signaling pathway }\end{array}$ \\
\hline$N S D 1$ & Nuclear receptor binding SET domain protein 1 & Lysine degradation \\
\hline PANK3 & Pantothenate kinase 3 & Pantothenate and CoA biosynthesis, \\
\hline POLR2J2, POLR2J3 & $\begin{array}{l}\text { Polymerase (RNA) II (DNA directed) polypeptide J3; } \\
\text { Polymerase (RNA) II (DNA directed) polypeptide J2 }\end{array}$ & $\begin{array}{l}\text { Purine metabolism, RNA polymerase, } \\
\text { Huntington's disease }\end{array}$ \\
\hline PPMIB & $\begin{array}{l}\text { Protein phosphatase 1B (formerly 2C), } \\
\text { Magnesium-dependent, beta isoform }\end{array}$ & MAPK signaling pathway \\
\hline PTPRF & Protein tyrosine phosphatase, receptor type, F & $\begin{array}{l}\text { Cell adhesion molecules (CAMs), } \\
\text { Insulin signaling pathway, }\end{array}$ \\
\hline TXNRD2 & Thioredoxin reductase 2 & Pyrimidine metabolism, \\
\hline TRA2A & Transformer 2 alpha homolog (Drosophila) & Spliceosome, \\
\hline$A K T 2$ & v-akt murine thymoma viral oncogene homolog 2 & $\begin{array}{l}\text { MAPK signaling pathway, ErbB signaling pathway, } \\
\text { mTOR signaling pathway, Apoptosis, VEGF signaling } \\
\text { pathway, Toll-like receptor signaling pathway, } \\
\text { Jak-STAT signaling pathway, Pathways in cancer, } \\
\text { Endometrial cancer, Glioma, Prostate cancer, Melanoma, } \\
\text { Acute myeloid leukemia, Small cell lung cancer, } \\
\text { Non-small cell lung cancer, }\end{array}$ \\
\hline
\end{tabular}

targeted tumor therapy (36-38). DNA damage induced by NCS possibly releases reactive oxygen species through an H2AX-Nox1/Rac1 pathway leading to the activation of a DNA damage repair mechanism (34). NQO1 (NAD (P) Quinone oxidoreductase) gene is involved in the protection of cytosolic enzymes in adaptive stress conditions, and also helps in the oxidation of NADH, which is a crucial component in cellular redox reactions. Moreover, it also stabilizes p53 and PARP1 activity (39). In our study, NQO1 was up-regulated in conjugate-treated MCF-7 cells, revealing the activation of stress responses in the tumor cells. PANK3, which is associated with the panthione synthesis pathway and in Acetyl-CoA production, facilitates the cellular redox process. The genes IFIT1, PANK3, and GCL3 are markers of DNA damage which are involved in cell proliferation and apoptosis (40). We observed that PANK3 and GCL3, are highly upregulated, indicating the activation of DNA damage response and induction of apoptosis. The most down-regulated genes in our study were AKT2, B4GALNT4, ZNF451 and PARP6, that are involved in the cell cycle process and DNA repair 


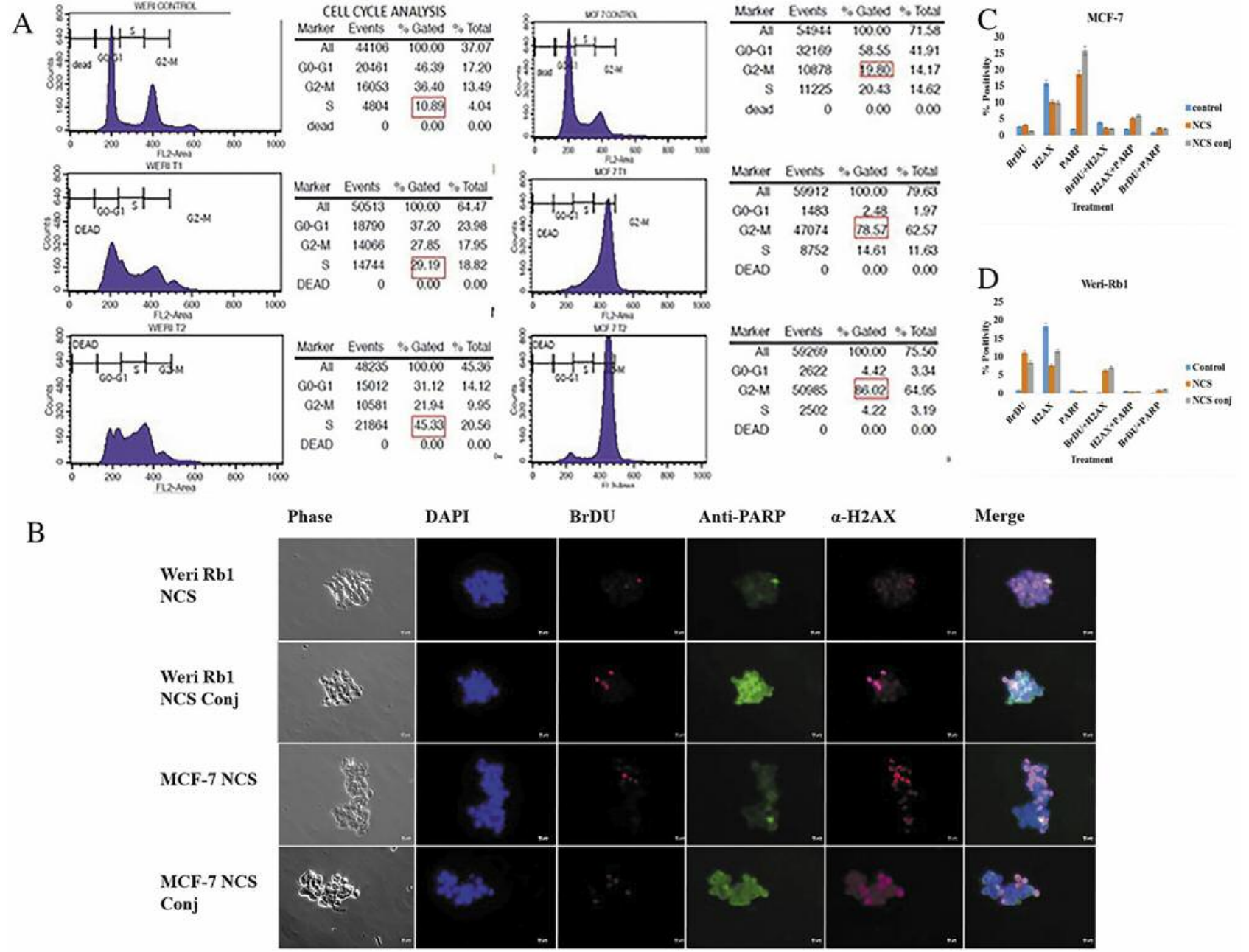

Figure 6. The aptamer internalization and cellular effects: (A) The cell-cycle analysis revealed the ' $G_{2}-M$ ' phase arrest in MCF-7 cell line with $N C S$ and Ep-NCSFi conjugate treatments. The WERI Rb1 cell line showed the retardation of ' $S$ ' phase or elongation of ' $S$ ' phase leading to phase arrest with NCS and Ep-NCSFi conjugate. $(B, C, D)$ The DNA damage was monitored by incorporation of BrDU, anti-PARP, and $\alpha-H 2 A X$. The intake of the BrDU in both NCS and Ep-NCSFi treatment was found to be minimal, which shows the reduction in the cell proliferation. The DNA-damage was monitored with the release of PARP enzyme, the release of PARP was clearly seen in NCS and Ep-NCSFi conjugate treatment. The overall PARP was highest in Ep-NCSFi conjugates comparatively with NCS. The $\alpha-H 2 A X$ also revealed that the increased levels of the $\alpha-H 2 A X$ in NCS and Ep-NCSFi conjugate treatments that were recruited by serine 139. Results $=$ Mean $\pm S E M * p<0.05, * * p<0.01$ and $* * * p<0.001$.

mechanisms (41). AKT2 is a thymoma viral oncogene homolog 2 that enhances cell migration, invasion, and proliferation (42) which has been hugely involved in various signaling pathways in cancers such as colorectal, pancreatic, prostate, non-small cell lung cancer, myeloid leukemia and glioma (KEGG) (Table I). Mosesson et al. reported that the integrin molecule is transported in the direction of cancer invasion by endocytosis of RAB12 (43). We found that RAB12 is highly downregulated in conjugate-treated cells, and this may be significant in the prevention of cancer invasion. PCB2 is involved in regulation of post-transcriptional and translational processes in stressed conditions (44). Complete down-regulation of PCB2 possibly reveals that conjugate treatment drive cells to necrosis. The epigenetic alteration predicted in conjugate-treated cells is evident by observing complete down-regulation of the PHF20L1 gene, which stabilizes methyltransferase activity in the genome (45). Knockdown of PolQ expression suppresses the DNA repair mechanism (46). Interestingly in our study, we witnessed a remarkable down-regulation of PolQ (47) which is involved in recruiting mitotic checkpoint proteins and regulating mitosis during DNA damage (48). In our study PCID2 was highly down-regulated which can be correlated to the inability of cells to overcome cell cycle arrest in the mitotic phase. 
$\mathbf{A}$

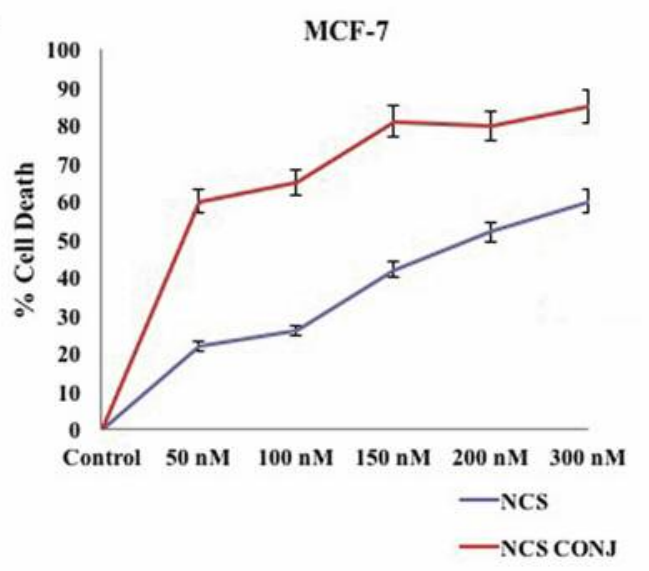

\section{B}

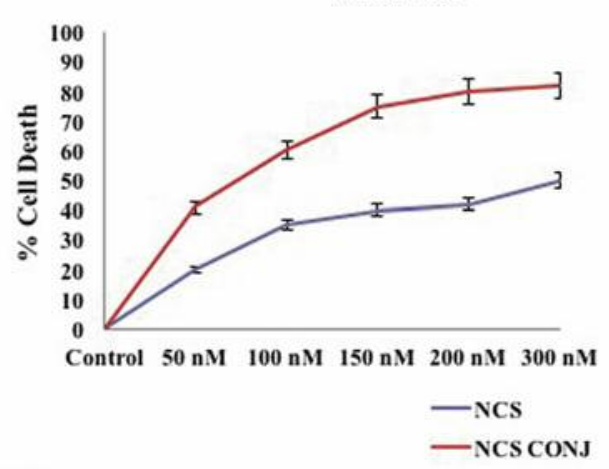

C

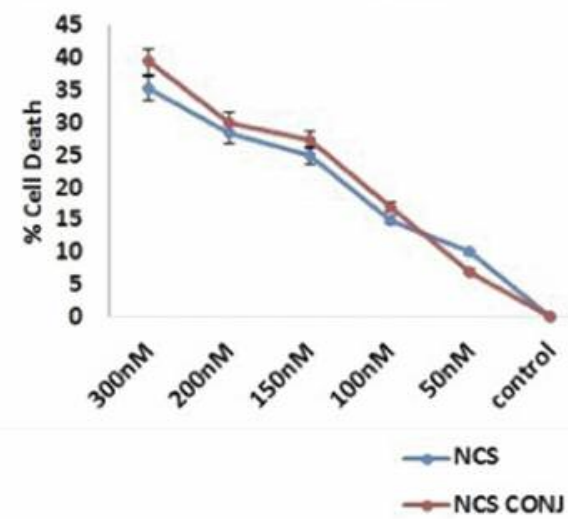

D

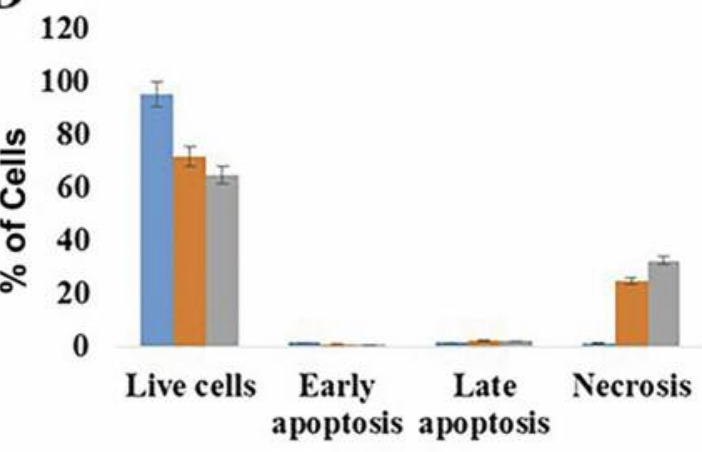

MCF-7

120

Cell stage

a control

$\because \mathrm{NCS}$

ㅁ NCS Conj

Weri Rb1

E

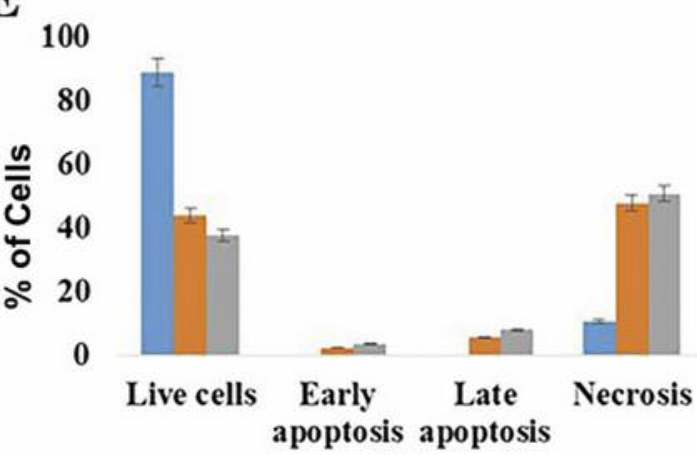

Cell Stage

an control

- NCS

nCS Conj

Figure 7. $(A, B, C)$ The trypan blue assay confirmed increase in cell death with increase in concentration in MCF-7 and WERI-Rb1 cell lines. (D\&E) The apoptosis-necrosis assay revealed the highest percentage of positivity of necrosis in both MCF-7 and WERI-Rb1 cell line through flow cytometry analysis. Results $=$ Mean \pm SEM $* p<0.05,{ }^{* *} p<0.01$ and ${ }^{* * *} p<0.001$.

Cell-cycle analysis revealed that NCS and the NCS conjugate caused $\mathrm{G}_{2}$ phase arrest in about 78 and $86 \%$ of MCF-7 cells respectively. On the other hand, NCS and conjugate induced S phase arrest in 29\% and 45\% of WERI-Rb1 cells respectively. The differences observed could be due to the variation in the biology of the tumor cells. BRCA1 which is a significant factor in the DNA repair pathway that helps tumor suppression was observed to be highly expressed in our microarray data $(49,50)$. Higher levels of cleaved poly (ADP-ribose) polymerase (PARP) were found in NCS conjugate-treated MCF-7 cells indicating that there was active participation of DNA repair detection and caspase-3 induction. Also, PARP detects double-strand breaks 


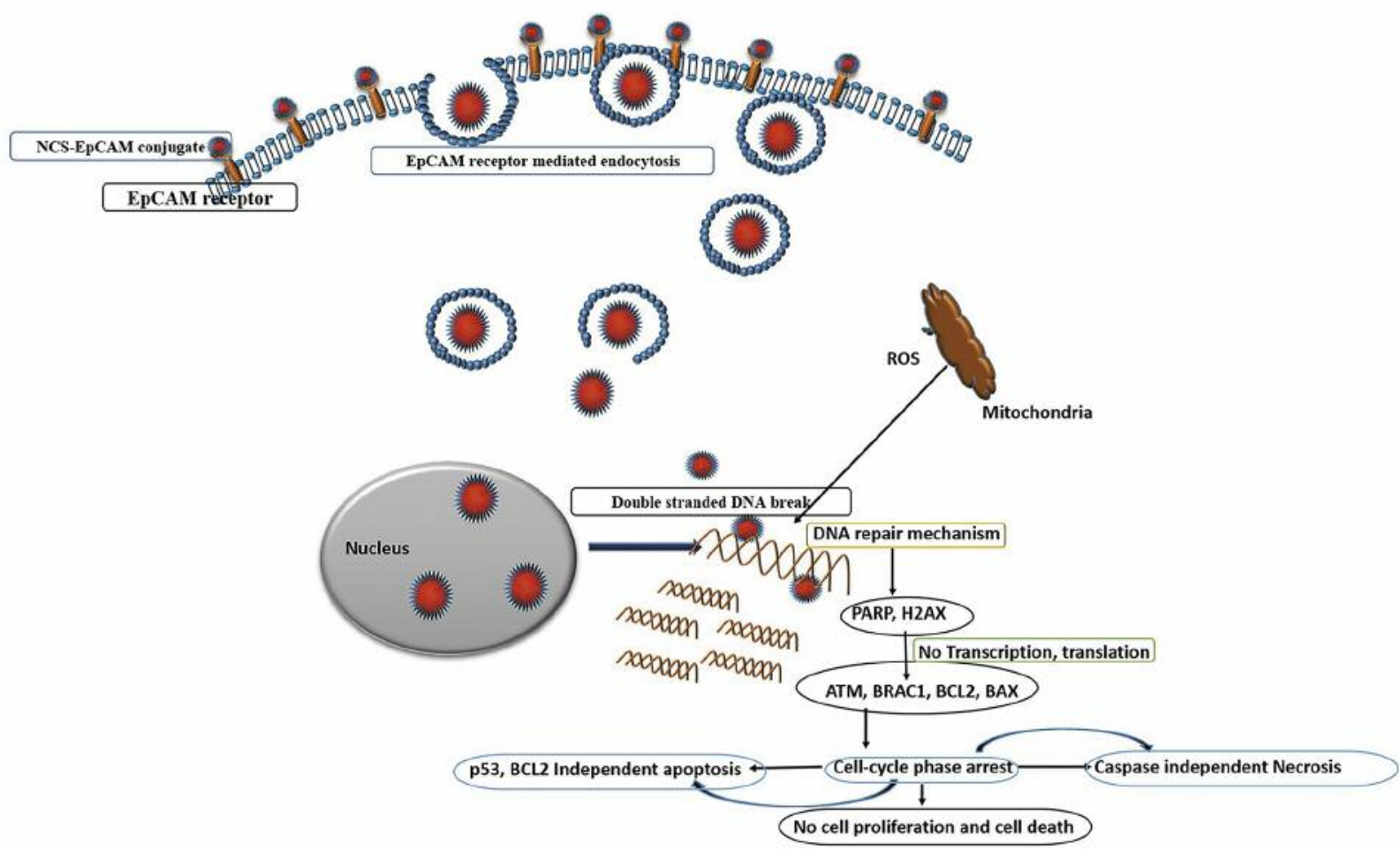

Figure 8. Schematics of genes involved in cell-cycle phase arrest and its down stream genes involved in apoptotic and necrotic processes in a NCS conjugate-treated cancer cells.

and immediately activates ATM signaling, which in turn increases $\mathrm{H} 2 \mathrm{~A}$ histone family member $\mathrm{X}(\mathrm{H} 2 \mathrm{AX})$ activity for the DNA repair mechanism to function $(49,51-53)$. There was less proliferation in NCS conjugate-treated cells as evidenced by BrdU incorporation in both MCF-7 and WERI-Rb1 cells. Lower levels of incorporation of $\mathrm{BrdU}$ in the growing population indicated that the conjugate induced DNA damage. The increased expression of H2AX has been reported in DNA damage conditions when treated with anti-cancer agents such as cisplatin (54). Higher expression of $\mathrm{H} 2 \mathrm{AX}$ in conjugatetreated cells due to DNA damage was evidenced (Figure 8). As a result, we observed more PARP-1 cleavage in treated cells. Early DNA damage response was triggered through recruitment of H2AX, and toxicity of conjugates rendered lethal damage to MCF-7 cells. However, in WERI-Rb1 cells, we did not observe increased levels of cleaved PARP1 thus cell deathoccured via a different unknown mechanism. Only a small increase in early apoptotic population from $0.04 \%$ to $2.56 \%$ and $3.4 \%$ in WERI$\mathrm{Rb} 1$ cells was observed. A similar profile was obtained for the late apoptotic population as well. More importantly, the necrotic population was increased (up to 50\%) in conjugate treated WERI-Rb1 cells. A similar pattern of necrosis was obtained for MCF-7 cells when treated with conjugates. This result is very much in agreement with the BrdU incorporation and $\mathrm{H} 2 \mathrm{AX}$ recruitment assay results in our study. Further, cell death was confirmed through the MTT and Trypan blue assays. $B C L-2$ family genes involved in apoptosis and necrosis were revealed in our Microarray study. Akito Sato et al. have shown that the transduction of $B C L-2$ genes leads to the releaseof cytochrome $C$, which enhances mitochondrial dysfunction and leads to apoptosis (55). Also, the mitochondrial dysfunction is also directed by $B A X$ genes that are members of the $B C L-2$ gene family. Mitochondrial dysfunction causes both necrosisand apoptosis $(56,57)$, which was clearly shown in our apoptotic data through Annexin-V and PI-stained flow cytometry results.

\section{Conclusion}

Our study demonstrates the effect of NCS on tumor cells when conjugated with the EpCAM aptamer. Conjugates deliver NCS to the EpCAM-positive cancer cells. The conjugates target the tumor cells by cleaving the DNA and thereby causing cell phase arrest. Microarray and BrDU assay revealed that the conjugate causes apoptosis and necrosis of tumor cells.

\section{Acknowledgements}

The Authors JN, KK, and PK would like to thank the department of Biotechnology, Government of India for funding the project: (NO.BT/PR2285/MED/31/128/2011, 29/12/2011). The Author PK would like to thank DBT for the SRF fellowship. The Authors would like to thank Dr. Rama Rajaram, VRF for critical suggestions 
in the manuscript and Dr. V. Umashankar, Bioinformatics Facility for helping with Gene Spring software. The Authors also thank Prof. P. Gautam, Anna University, Chennai, India for HPLC studies.

\section{Conflicts of Interest}

Authors declare no conflicts of interest.

\section{References}

1 Marin JJ, Romero MR, Blazquez AG, Herraez E, Keck E and Briz O: Importance and limitations of chemotherapy among the available treatments for gastrointestinal tumours. Anticancer Agents Med Chem 9: 162-184, 2009.

2 den Hollander P, Savage MI and Brown PH: Targeted therapy for breast cancer prevention. Front Oncol 3: 250, 2013.

3 Geiss R, De La Motte Rouge T, Dubot C, Leary A, Lhomme C, Pautier P, Scholl S and Rodrigues MJ: (Targeted therapy in locally and metastatic recurrent cervical cancers). Bull Cancer 101: 748-755, 2014.

4 Parums DV: Current status of targeted therapy in non-small cell lung cancer. Drugs Today 50: 503-525, 2014.

5 List T, Casi G, and Neri D: A chemically defined trifunctional antibody-cytokine-drug conjugate with potent antitumor activity. Mol Cancer Ther 13: 2641-2652, 2014.

6 Panowksi S, Bhakta S, Raab H, Polakis P and Junutula JR: Sitespecific antibody drug conjugates for cancer therapy. MAbs 6 : 34-45, 2014.

7 Kim CH, Axup JY, Lawson BR, Yun H, Tardif V, Choi SH, Zhou Q, Dubrovska A, Biroc SL, Marsden R, Pinstaff J, Smider VV and Schultz PG: Bispecific small molecule-antibody conjugate targeting prostate cancer. Proc Natl Acad Sci USA 110: 17796-17801, 2013.

8 Nevozhay D, Kanska U, Budzynska R and Boratynski J: Current status of research on conjugates and related drug delivery systems in the treatment of cancer and other diseases. Postepy Hig Med Dosw 61: 350-360, 2007.

9 Firer MA and Gellerman G. Targeted drug delivery for cancer therapy: the other side of antibodies. J Hematol Oncol 5: 70, 2012.

10 Ni X, Castanares M, Mukherjee A and Lupold SE: Nucleic acid aptamers: clinical applications and promising new horizons. Curr. Med. Chem 18: 4206-4214, 2011.

11 Trzpis M, McLaughlin PM, de Leij LM and Harmsen MC: Epithelial cell adhesion molecule: more than a carcinoma marker and adhesion molecule. Am J Pathol 171: 386-395, 2007.

12 Lin CW, Liao MY, Lin WW, Wang YP, Lu TY and Wu HC: Epithelial cell adhesion molecule regulates tumor initiation and tumorigenesis via activating reprogramming factors and epithelial-mesenchymal transition gene expression in colon cancer. J Biol Chem 287: 39449-39459, 2012.

13 Subramanian N, Raghunathan V, Kanwar JR, Kanwar RK, Elchuri SV, Khetan V and Krishnakumar S: Target-specific delivery of doxorubicin to retinoblastoma using epithelial cell adhesion molecule aptamer. Mol Vis 18: 2783-2795, 2012.

14 Subramanian N, Kanwar JR, Athalya PK, Janakiraman N, Khetan V, Kanwar RK, Eluchuri $S$ and Krishnakumar S: EpCAM aptamer mediated cancer cell specific delivery of EpCAM siRNA using polymeric nanocomplex. J Biomed Sci 22: 4, 2015.

15 Gilabert-Oriol R, Thakur M, von Mallinckrodt B, Hug T, Wiesner B, Eichhorst J, Melzig MF, Fuchs H and Weng A:
Modified trastuzumab and cetuximab mediate efficient toxin delivery while retaining antibody-dependent cell-mediated cytotoxicity in target cells. Mol Pharm 10: 4347-4357, 2013,

16 Hollevoet K, Antignani A, Fitzgerald DJ and Pastan I: Combining the antimesothelin immunotoxin SS1P with the BH3mimetic ABT-737 induces cell death in SS1P-resistant pancreatic cancer cells. J Immunother 37: 8-15, 2014,

17 Piao H, Kuan CT, Chandramohan V, Keir ST, Pegram CN, Bao $\mathrm{X}$, Mansson JE, Pastan IH and Bigner DD: Affinity-matured recombinant immunotoxin targeting gangliosides 3'-isoLM1 and 3',6'-isoLD1 on malignant gliomas. mAbs 5: 748-762, 2013.

18 Poenick S, Jahnke HG, Eichler M, Frost S, Lilie H and Robitzki AA: Comparative label-free monitoring of immunotoxin efficacy in $2 \mathrm{D}$ and $3 \mathrm{D}$ mamma carcinoma in vitro models by impedance spectroscopy. Biosens Bioelectron 53: 370-376, 2014.

19 Hensens OD, Chin DH, Stassinopoulos A, Zink DL, Kappen LS and Goldberg IH: Spontaneous generation of a biradical species of neocarzinostatin chromophore: role in DNA bulge-specific cleavage. Proc Natl Acad Sci USA 91: 4534-4538, 1994.

20 Kuromizu K, Tsunasawa S, Maeda H, Abe O and Sakiyama F: Reexamination of the primary structure of an antitumor protein, neocarzinostatin. Arch Biochem Biophys 246: 199-205, 1986.

21 Napier MA, Holmquist B, Strydom DJ and Goldberg IH: Neocarzinostatin: spectral characterization and separation of a non-protein chromophore. Biochem Biophys Res Commun 89: 635-642, 1979.

22 Goldberg IH: Mechanism of neocarzinostatin action: role of DNA microstructure in determination of chemistry of bistranded oxidative damage. Acc Chem Res 24: 191-198, 1991.

23 Otsuji E, Yamaguchi T, Tsuruta H, Yata Y, Nishi H, Okamoto K, Taniguchi K, Kato M, Kotani T, Kitamura K and Takahashi T: Effects of neocarzinostatin-chimeric Fab conjugates on the growth of human pancreatic carcinoma xenografts. Br J Cancer 73: 1178-1182, 1996.

24 Luders G, Kohnlein W, Sorg C and Bruggen J: Selective toxicity of neocarzinostatin-monoclonal antibody conjugates to the antigen-bearing human melanoma cell line in vitro. Cancer Immunol Immunother 20: 85-90, 1985.

25 Yamaguchi T, Tsurumi H, Kotani T, Yamaoka N, Otsuji E, Kitamura $\mathrm{K}$ and Takahashi $\mathrm{T}$ : In vivo efficacy of neocarzinostatin coupled with Fab human/mouse chimeric monoclonal antibody A7 against human colorectal cancer. Jpn J Cancer Res 85: 167-171, 1994.

26 Hicke BJ and Stephens AW: Escort aptamers: a delivery service for diagnosis and therapy. J Clin Invest 106: 923-928, 2000.

27 Athyala PK, Kanwar JR, Alameen M, Kanwar RK, Krishnakumar S, Watson J, Vetrivel U and Narayanan J: Probing the biophysical interaction between Neocarzinostatin toxin and EpCAM RNA aptamer. Biochem Biophys Res Commun 469: 257-262, 2016.

28 Schussler O, Coirault C, Louis-Tisserand M, Al-Chare W, Oliviero P, Menard C, Michelot R, Bochet P, Salomon DR, Chachques JC, Carpentier A and Lecarpentier Y: Use of arginine-glycine-aspartic acid adhesion peptides coupled with a new collagen scaffold to engineer a myocardium-like tissue graft. Nat Clin Pract Cardiovasc Med 6: 240-249, 2009.

29 Kavimandan NJ, Losi E, Wilson JJ, Brodbelt JS and Peppas NA: Synthesis and characterization of insulin-transferrin conjugates. Bioconjug Chem 17: 1376-1384, 2006. 
30 Huang da W, Sherman BT and Lempicki RA: Systematic and integrative analysis of large gene lists using DAVID bioinformatics resources. Nat Protoc 4: 44-57, 2009.

31 Simon M, Stefan N, Pluckthun A and Zangemeister-Wittke U: Epithelial cell adhesion molecule-targeted drug delivery for cancer therapy. Expert Opin Drug Deliv 10: 451-468, 2013.

32 Chu TC, Marks JW, 3rd, Lavery LA, Faulkner S, Rosenblum MG, Ellington AD and Levy M: Aptamer:toxin conjugates that specifically target prostate tumor cells. Cancer Res 66: 59895992, 2006

33 Blank M, Weinschenk T, Priemer $M$ and Schluesener H: Systematic evolution of a DNA aptamer binding to rat brain tumor microvessels. selective targeting of endothelial regulatory protein pigpen. J Biol Chem 276: 16464-16468, 2001.

34 Kang MA, So EY, Simons AL, Spitz DR and Ouchi T: DNA damage induces reactive oxygen species generation through the H2AX-Nox1/Rac1 pathway. Cell Death Dis 3: e249, 2012.

35 Banuelos A, Reyes E, Ocadiz R, Alvarez E, Moreno M, Monroy A and Gariglio P: Neocarzinostatin induces an effective p53dependent response in human papillomavirus-positive cervical cancer cells. J Pharm Exp Ther 306: 671-680, 2003.

36 Mischel PS, Cloughesy TF and Nelson SF: DNA-microarray analysis of brain cancer: molecular classification for therapy. Nat Rev Neurosci 5: 782-792, 2004

37 Yamanaka R, Arao T, Yajima N, Tsuchiya N, Homma J, Tanaka R, Sano M, Oide A, Sekijima M and Nishio K: Identification of expressed genes characterizing long-term survival in malignant glioma patients. Oncogene 25: 5994-6002, 2006.

38 Matsumoto K, Arao T, Tanaka K, Kaneda H, Kudo K, Fujita Y, Tamura D, Aomatsu K, Tamura T, Yamada Y, Saijo N and Nishio $\mathrm{K}$ : mTOR signal and hypoxia-inducible factor-1 alpha regulate CD133 expression in cancer cells. Cancer Res 69: 7160-7164, 2009.

39 Cresteil T and Jaiswal AK: High levels of expression of the $\mathrm{NAD}(\mathrm{P}) \mathrm{H}$ :quinone oxidoreductase (NQO1) gene in tumor cells compared to normal cells of the same origin. Biochem Pharmacol 42: 1021-1027, 1991.

40 Weichselbaum RR, Ishwaran H, Yoon T, Nuyten DS, Baker SW, Khodarev, N, Su AW, Shaikh AY, Roach P, Kreike B and Roizman $\mathrm{B}$ : An interferon-related gene signature for DNA damage resistance is a predictive marker for chemotherapy and radiation for breast cancer. Proc Natl Acad Sci USA 105: 18490-18495, 2008.

41 Tuncel H, Tanaka S, Oka S, Nakai S, Fukutomi R, Okamoto M, Ota T, Kaneko H, Tatsuka M and Shimamoto F: PARP6, a mono(ADP-ribosyl) transferase and a negative regulator of cell proliferation, is involved in colorectal cancer development. Int J Oncol 41: 2079-2086, 2012.

42 Cheng GZ, Chan J, Wang Q, Zhang W, Sun CD and Wang LH: Twist transcriptionally up-regulates AKT2 in breast cancer cells leading to increased migration, invasion, and resistance to paclitaxel. Cancer Res 67: 1979-1987, 2007.

43 Iida $H$, Noda $M$, Kaneko $T$, Doiguchi $M$ and Mori $T$ : Identification of rab12 as a vesicle-associated small GTPase highly expressed in Sertoli cells of rat testis. Mol Reprod Dev 71: 178-185, 2005.

44 Han W, Xin Z, Zhao Z, Bao W, Lin X, Yin B, Zhao J, Yuan J, Qiang $\mathrm{B}$ and Peng $\mathrm{X}$ : RNA-binding protein PCBP2 modulates glioma growth by regulating FHL3. J Clin Invest 123: 2103-2118, 2013.

45 Esteve PO, Terragni J, Deepti K, Chin HG, Dai N, Espejo A, Correa IR Jr, Bedford MT and Pradhan S: Methyllysine reader plant homeodomain (PHD) finger protein 20-like 1 (PHF20L1) antagonizes DNA (cytosine-5) methyltransferase 1 (DNMT1) proteasomal degradation. J Biol Chem 289: 8277-8287, 2014.

46 Mateos-Gomez PA, Gong F, Nair N, Miller KM, LazzeriniDenchi E and Sfeir A: Mammalian polymerase theta promotes alternative NHEJ and suppresses recombination. Nature 518: 254-257, 2015.

47 Ceccaldi R, Liu JC, Amunugama R, Hajdu I, Primack B, Petalcorin MI, O'Connor KW, Konstantinopoulos PA, Elledge SJ, Boulton SJ, Yusufzai T and D'Andrea AD: Homologousrecombination-deficient tumours are dependent on Polthetamediated repair. Nature 518: 258-262, 2015.

48 Nakaya T, Kuwahara K, Ohta K, Kitabatake M, Toda T, Takeda $\mathrm{N}$, Tani T, Kondo E and Sakaguchi N: Critical role of Pcid2 in B cell survival through the regulation of MAD2 expression. J Immunol 185: 5180-5187, 2010.

49 Xu G, Chapman JR, Brandsma I, Yuan J, Mistrik M, Bouwman P, Bartkova J, Gogola E, Warmerdam D, Barazas M, Jaspers JE, Watanabe K, Pieterse M, Kersbergen A, Sol W, Celie PH, Schouten PC, van den Broek B, Salman A, Nieuwland M, de Rink I, de Ronde J, Jalink K, Boulton SJ, Chen J, van Gent DC, Bartek J, Jonkers J, Borst P and Rottenberg S: REV7 counteracts DNA double-strand break resection and affects PARP inhibition. Nature 521: 541-544, 2015.

50 Roy R, Chun J and Powell SN: BRCA1 and BRCA2: different roles in a common pathway of genome protection. Nat Rev Cancer 12: 68-78, 2012.

51 Haince JF, Kozlov S, Dawson VL, Dawson TM, Hendzel MJ, Lavin MF and Poirier GG: Ataxia telangiectasia mutated (ATM) signaling network is modulated by a novel poly(ADP-ribose)dependent pathway in the early response to DNA-damaging agents. J Biol Chem 282: 16441-16453, 2007.

52 Bencokova Z, Kaufmann MR, Pires IM, Lecane PS, Giaccia AJ and Hammond EM: ATM activation and signaling under hypoxic conditions. Mol Cell Biol 29: 526-537, 2009.

53 Altmeyer M, Toledo L, Gudjonsson T, Grofte M, Rask MB and Lukas C, Akimov V, Blagoev B, Bartek J and Lukas J: The chromatin scaffold protein SAFB1 renders chromatin permissive for DNA damage signaling. Mol Cell 52: 206-220, 2013.

54 Lundholm L, Haag P, Zong D, Juntti T, Mork B, Lewensohn R and Viktorsson: Resistance to DNA-damaging treatment in nonsmall cell lung cancer tumor-initiating cells involves reduced DNA-PK/ATM activation and diminished cell cycle arrest. Cell Death Dis 4: e478, 2013.

55 Sato A, Hiramoto A, Uchikubo Y, Miyazaki E, Satake A and Naito T, Hiraoka O, Miyake T, Kim HS and Wataya Y: Gene expression profiles of necrosis and apoptosis induced by 5fluoro-2'-deoxyuridine. Genomics 92: 9-17, 2008.

56 Nakagawa T, Shimizu S, Watanabe T, Yamaguchi O, Otsu K, Yamagata H, Inohara H, Kubo T and Tsujimoto Y: Cyclophilin Ddependent mitochondrial permeability transition regulates some necrotic but not apoptotic cell death. Nature 434: 652-658, 2005.

57 Green DR and Kroemer G: The Pathophysiology of Mitochondrial Cell Death. Science 305: 626-629, 2004.

Received April 28, 2017

Revised May 28, 2017

Accepted June 6, 2017 